\title{
Response to: A commentary on "Antipsychotic-induced parkinsonism is associated with working memory deficits in schizophrenia-spectrum disorders"
}

\author{
Stéphane Potvin ${ }^{1,2 *}$ and Andràs Tikàsz ${ }^{1,2}$ \\ ${ }^{1}$ Centre de Recherche de I'Institut Universitaire en Santé Mentale de Montréal, Montreal, QC, Canada, ${ }^{2}$ Department of \\ Psychiatry, Faculty of Medicine, University of Montreal, Montreal, QC, Canada
}

Keywords: schizophrenia, parkinsonism, extrapyramidal symptom, dosage equivalency, cognition

\section{A response to}

A commentary on "Antipsychotic-induced parkinsonism is associated with working memory deficits in schizophrenia-spectrum disorders"

by Salem, A. and Moustafa, A. A. (2015). Front. Behav. Neurosci. 9, 131. doi: 10.3389/fnbeh.2015.00131

\section{OPEN ACCESS}

Edited by:

Edo Ronald De Kloet, Leiden University, Netherlands

Reviewed by: Marc-André Roy, Université Laval, Canada

*Correspondence: Stéphane Potvin stephane.potvin@umontreal.ca

Received: 18 June 2015 Accepted: 27 July 2015 Published: 12 August 2015

Citation:

Potvin S and Tikàsz A (2015)

Response to: A commentary on "Antipsychotic-induced parkinsonism is associated with working memory deficits in schizophrenia-spectrum disorders".

Front. Behav. Neurosci. 9:210. doi: 10.3389/fnbeh.2015.00210
We read with interest the commentary from Drs Salem and Moustafa (2015) on our paper and we would like to take the opportunity to further discuss two issues, namely, the use of chlorpromazine equivalents (CPZs) to control for the effects of antipsychotics and the need for longitudinal studies examining the complex relationships between cognition and antipsychotic-induced extrapyramidal symptoms (EPS) in schizophrenia.

Drs Salem and Moustafa suggested calculating CPZs as means to rule out confounding dosage and variations in drugs. Although we agree with the notion put forward by the authors, especially in the context of a study investigating the side effects of antipsychotics, we would like to reiterate that there is yet to be a widely accepted robust antipsychotic dosage comparison system that reliably yields consistent equivalences across drugs (Patel et al., 2013). CPZs can be obtained via one of three calculations described by Patel et al. (2013): the mean effective dose in flexible-dose studies, the minimum effective dose, and the consensus of experts method. These methods yield inconsistent results particularly in the case of antipsychotics with low affinities for dopamine- $\mathrm{D}_{2}$ receptors (Sweileh et al., 2014). In our study, out of 82 schizophrenia-spectrum patients, 24 patients were treated with clozapine and 18 with quetiapine. In the literature, we note significant fluctuations in CPZs for quetiapine (60-175.5 mg/day) and clozapine (50-138.8 mg/day), an ambiguity highlighted when the two drugs are considered relative to one another (see Table S1 in Supplementary Material). In fact, depending on the CPZ calculation method, quetiapine will be considered more or less potent than clozapine. Therefore, even when only one equivalence system is employed, the comparison of antipsychotic medication dosage between studies for an individual drug is troublesome, and interpreting between-drug differences is problematic. The limited number of studies comparing directly atypical antipsychotics to chlorpromazine, an older typical antipsychotic, might explain some of the variability between the CPZ calculations. Nevertheless, when examining olanzapine equivalents, a system based on the availability of a larger set of randomized-controlled trials (RCTs) (Leucht et al., 2014, 2015), significant discrepancies between calculation methods of over 30\% can 
TABLE 1 | Review of the studies included in the meta-analysis from Nielsen et al. (2015).

\begin{tabular}{|c|c|c|c|c|c|c|c|c|}
\hline Reference & Antipsychotics & $\begin{array}{l}\text { Duration } \\
\text { (weeks) }\end{array}$ & $N$ & AntiCh & $\begin{array}{l}\text { AnticCh- } \\
\text { cognition } \\
\text { association }\end{array}$ & $\begin{array}{l}\text { EPS } \\
\text { scale }\end{array}$ & $\begin{array}{c}\text { EPS- } \\
\text { cognition } \\
\text { association }\end{array}$ & Cognitive functions \\
\hline Bellack et al. (2004) & Clozapine, risperidone & 29 & 22 & - & - & - & - & - \\
\hline Bender et al. (2006) & Clozapine, olanzapine & 26 & 31 & Allowed & - & SAS & No & Executive functioning \\
\hline Bilder et al. (2002) & $\begin{array}{l}\text { Clozapine, olanzapine, } \\
\text { risperidone, haloperidol }\end{array}$ & 14 & 101 & Allowed & Yes & ESRS & Yes & $\begin{array}{l}\text { Composite index (general executive and perceptual organization, declarative verbal } \\
\text { learning and memory, processing speed and attention, simple motor functioning) }\end{array}$ \\
\hline Buchanan et al. (1994) & Clozapine, haloperidol & 10 & 38 & Allowed & - & SAS & Yes & Visual memory \\
\hline Davidson et al. (2009) & $\begin{array}{l}\text { Amisulpride, quetiapine, } \\
\text { ziprasidone, haloperidol }\end{array}$ & 26 & 320 & Allowed & - & SHRS & - & - \\
\hline Gallhofer et al. (2007) & Sertindole, haloperidol & 12 & 32 & Excluded & - & SAS & No & Speed and attention, executive functioning \\
\hline Gurpegui et al. (2007) & Olanzapine, risperidone & 48 & 163 & Allowed & - & - & - & - \\
\hline Harvey et al. (2008) & Clozapine, ziprasidone & 12 & 100 & - & - & - & - & - \\
\hline Harvey et al. (2003) & Olanzapine, risperidone & 8 & 267 & Allowed & No & ESRS & Yes & Verbal memory, vigilance \\
\hline Harvey et al. (2006a) & Olanzapine, ziprasidone & 26 & 72 & - & - & ESRS & No & Attention, task switching, verbal memory, executive functioning, verbal fluency \\
\hline Harvey et al. (2006b) & Quetiapine, risperidone & 8 & 289 & - & - & - & - & - \\
\hline Honer et al. (2006) & $\begin{array}{l}\text { Clozapine + risperidone or } \\
\text { clozapine + placebo }\end{array}$ & 8 & 65 & Allowed & - & ESRS & - & - \\
\hline Jerrell and Ramirez (2008) & $\begin{array}{l}\text { Olanzapine, risperidone, } \\
\text { typical antipsychotic drugs }\end{array}$ & 52 & 108 & Allowed & No & - & - & - \\
\hline Keefe et al. (2007b) & $\begin{array}{l}\text { Olanzapine, quetiapine, } \\
\text { risperidone }\end{array}$ & 52 & 81 & Allowed & No & SAS & No & $\begin{array}{l}\text { Composite index (processing speed, reasoning and problem solving, verbal } \\
\text { memory and working memory, vigilance) }\end{array}$ \\
\hline Keefe et al. (2007a) & $\begin{array}{l}\text { Olanzapine, quetiapine, } \\
\text { risperidone, ziprasidone, } \\
\text { perphenazine }\end{array}$ & 78 & 128 & Allowed & Yes & SAS & Yes & $\begin{array}{l}\text { Composite index (processing speed, reasoning, working memory, verbal memory, } \\
\text { vigilance) }\end{array}$ \\
\hline Krakowski et al. (2008) & $\begin{array}{l}\text { Clozapine, olanzapine, } \\
\text { haloperidol }\end{array}$ & 12 & 100 & Allowed & - & ESRS & No & $\begin{array}{l}\text { Composite index (motor, executive function, verbal memory, visual memory, } \\
\text { visuospatial ability, visual motor tracking, attention) }\end{array}$ \\
\hline Lee et al. (1999) & $\begin{array}{l}\text { Clozapine, Typical } \\
\text { antipsychotic drugs }\end{array}$ & 52 & 52 & Allowed & No & SAS & Yes & Verbal fluency, executive functioning, verbal working memory \\
\hline Lee et al. (2007) & Risperidone, haloperidol & 8 & 20 & - & - & - & - & - \\
\hline Lindenmayer et al. (2007) & Olanzapine, haloperidol & 12 & 33 & Allowed & - & SAS & - & - \\
\hline Ljubin et al. (2000) & Olanzapine, fluphenazine & 22 & 18 & - & - & - & - & - \\
\hline McGurk et al. (2005) & Clozapine, risperidone & 29 & 35 & - & - & - & - & - \\
\hline Meltzer et al. (2008) & Clozapine, olanzapine & 26 & 24 & Allowed & - & SAS & - & - \\
\hline Mori et al. (2004) & $\begin{array}{l}\text { Olanzapine, perospirone, } \\
\text { quetiapine, risperidone }\end{array}$ & 12 & 77 & Allowed & Yes & - & - & - \\
\hline Mortimer et al. (2007) & Amisulpride, olanzapine & 26 & 18 & Excluded & - & AIMS & - & - \\
\hline Muscatello et al. (2011) & $\begin{array}{l}\text { Aripiprazole + clozapine or } \\
\text { placebo + clozapine }\end{array}$ & 24 & 31 & - & - & - & - & - \\
\hline Ernst Nielsen et al. (2014) & $\begin{array}{l}\text { Clozapine }+ \text { sertindole or } \\
\text { clozapine + placebo }\end{array}$ & 12 & 50 & Allowed & - & - & - & - \\
\hline
\end{tabular}




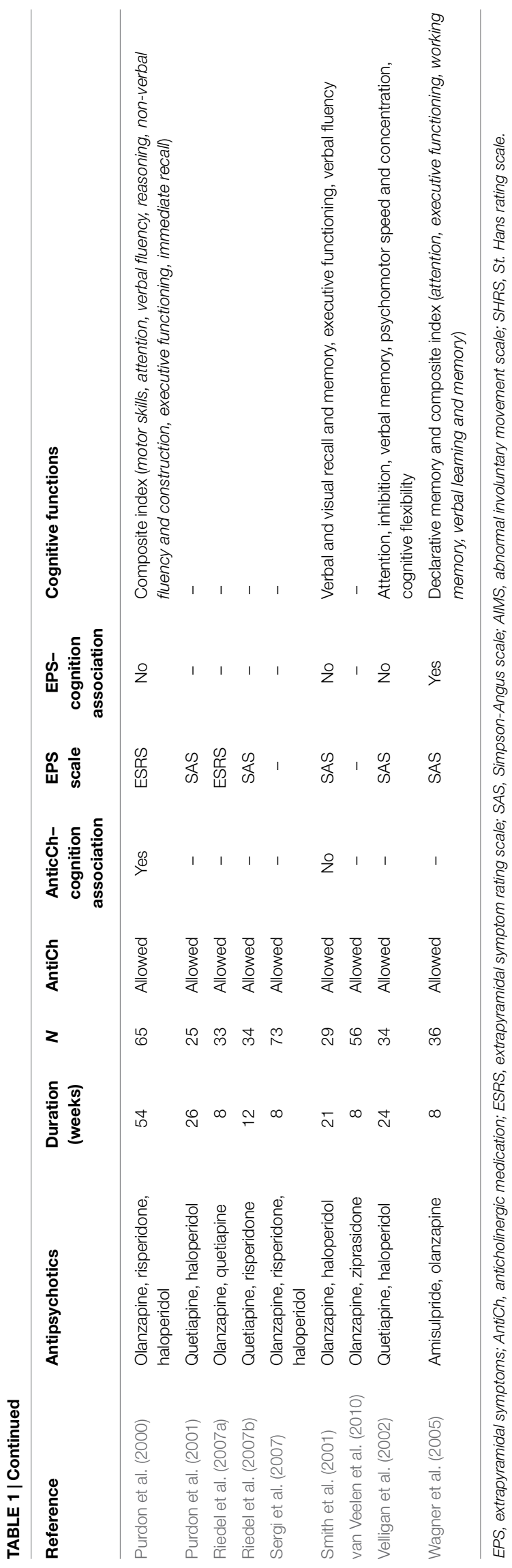

be observed for both quetiapine $(20-32.3 \mathrm{mg} /$ day $)$ and clozapine $(30.6-40 \mathrm{mg} /$ day) (see Table S1 in Supplementary Material). Other than CPZ, Daily Defined Doses (DDD) is a popular platform developed to compare drug utilization (Danivas and Venkatasubramanian, 2013). It is not, however, a measure of therapeutic efficacy like CPZ (Patel et al., 2013). Finally, equivalents of dopamine- $\mathrm{D}_{2}$ receptor occupancy appears as a relevant system amongst the remaining alternatives, as it targets a key neuropharmacological mechanism involved in the emergence of antipsychotic-induced EPS (de Greef et al., 2011). Indeed, several positron emission tomography studies have shown that antipsychotics are more likely to produce EPS at dosages associated with striatal $\mathrm{D}_{2}$ occupancy higher than $80 \%$ (Kapur and Seeman, 2001). However, the role of $D_{2}$ receptors in the pathophysiology of EPS (dystonia, dyskinesia, akathisia) other than parkinsonism is less clear (Mehta et al., 2015). Moreover, antipsychotics bind several receptors other than $\mathrm{D}_{2}$ contributing to, or preventing, the emergence of EPS, such as dopamine $\mathrm{D}_{3}, \mathrm{D}_{4}$, serotonin 5$\mathrm{HT}_{2 \mathrm{~A}}$, and $\alpha_{1}$-adrenergic receptors (Horacek, 2000). For these reasons, the $\mathrm{D}_{2}$ equivalency method can be reductionist. In sum, until a consistent reliable system is developed and implemented, utilizing one dosage equivalence system versus another is likely to introduce significant caveats in the interpretation of experimental results, especially in the case of studies including patients treated with clozapine or quetiapine.

The second issue that we wanted to raise concerns the fact that most studies investigating the relationship between cognition and EPS in schizophrenia are based on cross-sectional designs, which are more vulnerable to confounding factors than longitudinal designs. As rightly mentioned by Drs Salem and Moustafa, we sought to overcome this problem in our study by performing hierarchical multivariate linear regression analyses incorporating several socio-demographic and psychiatric variables likely to influence the cognition-EPS association (Potvin et al., 2015). Still, we feel that longitudinal studies are required in order to clarify the temporal dynamics of the association we observed between cognition (e.g., working memory) and drug-induced Parkinsonism. Interestingly, several RCTs have examined the effects of antipsychotics on cognition, which provide an opportunity to study the cognition-EPS association in a longitudinal fashion. The study of the cognition-EPS association is particularly relevant in this context, since it is theoretically possible that the presumed beneficial effects of second-generation antipsychotics (SGAs) on cognition are actually explained by the lower liability of these drugs to induce EPS, compared to first-generation antipsychotics (Leucht et al., 2013). It must also be considered that by causing fewer EPS, the treatment with SGAs renders the prescription of adjuvant anticholinergic drugs less necessary, the latter being well-known to impair cognition (Bubser et al., 2012). Recent meta-analyses have shown that the beneficial effects of SGAs (risperidone and olanzapine) on cognition are small-to-moderate (Desamericq et al., 2014). These benefits may not only reflect true effects but also be confounded by the effects of EPS and/or anticholinergics. Therefore, we reviewed 35 RCTs included in a recent meta-analysis from Nielsen et al. (2015) on the effects of antipsychotic on cognition in schizophrenia and systematically retrieved information on anticholinergics, EPS scales, EPS-cognition associations, 
and cognitive tests (see Table 1). Of the 35 RCTs reviewed, 12 studies did not measure EPS. Of the remaining 23 studies, only 14 performed statistics on potential associations between EPS and cognition. Of these, six trials found an association between EPS and cognition, and eight did not. Although such results do not firmly establish a relationship between EPS and cognition, they do not rule it out either, especially since the mean duration of trials was 24 weeks, which may not be long enough to detect associations between EPS and cognition in schizophrenia. To our knowledge, the most reliable associations highlighted in cross-sectional studies are between cognition and tardive dyskinesia (Pantelis et al., 2001; Wu et al., 2013), which typically occurs later during treatment than akathisia, dystonia, and parkinsonism. Also of methodological concern, among the 35 RCTs reviewed, only 2 studies excluded anticholinergic drugs (Note: 8 trials did not report information on anticholinergics). Moreover, of the 25 remaining trials, only 9 studies examined potential associations between changes in cognitive performance and the prescription of adjuvant anticholinergics. At a time when the pharmacological treatment of cognitive deficits in schizophrenia is recognized as a top clinical priority,

\section{References}

Bellack, A. S., Schooler, N. R., Marder, S. R., Kane, J. M., Brown, C. H., and Yang, Y. (2004). Do clozapine and risperidone affect social competence and problem solving? Am. J. Psychiatry 161, 364-367. doi:10.1176/appi.ajp.161.2.364

Bender, S., Dittmann-Balcar, A., Schall, U., Wolstein, J., Klimke, A., Riedel, M., et al. (2006). Influence of atypical neuroleptics on executive functioning in patients with schizophrenia: a randomized, double-blind comparison of olanzapine vs. clozapine. Int. J. Neuropsychopharmacol. 9, 135-145. doi:10.1017/ S1461145705005924

Bilder, R. M., Goldman, R. S., Volavka, J., Czobor, P., Hoptman, M., Sheitman, B., et al. (2002). Neurocognitive effects of clozapine, olanzapine, risperidone, and haloperidol in patients with chronic schizophrenia or schizoaffective disorder. Am. J. Psychiatry 159, 1018-1028. doi:10.1176/appi.ajp.159.6.1018

Bubser, M., Byun, N., Wood, M. R., and Jones, C. K. (2012). Muscarinic receptor pharmacology and circuitry for the modulation of cognition. Handb. Exp. Pharmacol. 208, 121-166. doi:10.1007/978-3-642-23274-9_7

Buchanan, R. W., Holstein, C., and Breier, A. (1994). The comparative efficacy and long-term effect of clozapine treatment on neuropsychological test-performance. Biol. Psychiatry 36, 717-725. doi:10.1016/0006-3223(94) 90082-5

Danivas, V., and Venkatasubramanian, G. (2013). Current perspectives on chlorpromazine equivalents: comparing apples and oranges! Indian J. Psychiatry 55, 207-208. doi:10.4103/0019-5545.111475

Davidson, M., Galderisi, S., Weiser, M., Werbeloff, N., Fleischhacker, W. W., Keefe, R. S., et al. (2009). Cognitive effects of antipsychotic drugs in first-episode schizophrenia and schizophreniform disorder: a randomized, open-label clinical trial (EUFEST). Am. J. Psychiatry 166, 675-682. doi:10.1176/appi.ajp.2008. 08060806

de Greef, R., Maloney, A., Olsson-Gisleskog, P., Schoemaker, J., and Panagides, J. (2011). Dopamine D2 occupancy as a biomarker for antipsychotics: quantifying the relationship with efficacy and extrapyramidal symptoms. AAPS J. 13, 121-130. doi:10.1208/s12248-010-9247-4

Desamericq, G., Schurhoff, F., Meary, A., Szoke, A., Macquin-Mavier, I., BachoudLevi, A. C., et al. (2014). Long-term neurocognitive effects of antipsychotics in schizophrenia: a network meta-analysis. Eur. J. Clin. Pharmacol. 70, 127-134. doi:10.1007/s00228-013-1600-y

Ernst Nielsen, R., Odur, F., Ostergaard, T., Munk-Jorgensen, P., and Nielsen, J. (2014). Comparison of the effects of sertindole and olanzapine on cognition (SEROLA): a double-blind randomized 12-week study of patients diagnosed with schizophrenia. Ther. Adv. Psychopharmacol. 4, 4-14. doi:10.1177/ 2045125313499065 the lack of knowledge on the above-mentioned factors impedes our ability to reach valid conclusions on the presumed superior efficacy of SGAs (mostly risperidone and olanzapine) on cognition in schizophrenia. In return, these limitations undermine the ongoing debate about the pharmacological mechanisms that should be targeted to improve cognitive performance in schizophrenia.

\section{Author Contributions}

SP and AT wrote the commentary.

\section{Acknowledgments}

SP is holder of the Eli Lilly Chair on schizophrenia research from University of Montreal.

\section{Supplementary Material}

The Supplementary Material for this article can be found online at http://journal.frontiersin.org/article/10.3389/fnbeh.2015.00210

Gallhofer, B., Jaanson, P., Mittoux, A., Tanghoj, P., Lis, S., and Krieger, S. (2007). Course of recovery of cognitive impairment in patients with schizophrenia: a randomised double-blind study comparing sertindole and haloperidol. Pharmacopsychiatry 40, 275-286. doi:10.1055/s-2007-990291

Gurpegui, M., Alvarez, E., Bousono, M., Ciudad, A., Gomez, J. C., and Olivares, J. M. (2007). Effect of olanzapine or risperidone treatment on some cognitive functions in a one-year follow-up of schizophrenia outpatients with prominent negative symptoms. Eur. Neuropsychopharmacol. 17, 725-734. doi:10.1016/j. euroneuro.2007.04.003

Harvey, P. D., Bowie, C. R., and Loebel, A. (2006a). Neuropsychological normalization with long-term atypical antipsychotic treatment: results of a sixmonth randomized, double-blind comparison of ziprasidone vs. olanzapine. J. Neuropsychiatry Clin. Neurosci. 18, 54-63. doi:10.1176/appi.neuropsych.18.1.54

Harvey, P. D., Patterson, T. L., Potter, L. S., Zhong, K., and Brecher, M. (2006b). Improvement in social competence with short-term atypical antipsychotic treatment: a randomized, double-blind comparison of quetiapine versus risperidone for social competence, social cognition, and neuropsychological functioning Am. J. Psychiatry 163, 1918-1925. doi:10.1176/appi.ajp.163.11.1918

Harvey, P. D., Green, M. F., McGurk, S. R., and Meltzer, H. Y. (2003). Changes in cognitive functioning with risperidone and olanzapine treatment: a large-scale, double-blind, randomized study. Psychopharmacology (Berl.) 169, 404-411. doi: 10.1007/s00213-002-1342-5

Harvey, P. D., Sacchetti, E., Galluzzo, A., Romeo, F., Gorini, B., Bilder, R. M., et al. (2008). A randomized double-blind comparison of ziprasidone vs. clozapine for cognition in patients with schizophrenia selected for resistance or intolerance to previous treatment. Schizophr. Res. 105, 138-143. doi:10.1016/j.schres.2007. 11.014

Honer, W. G., Thornton, A. E., Chen, E. Y., Chan, R. C., Wong, J. O., Bergmann, A., et al. (2006). Clozapine alone versus clozapine and risperidone with refractory schizophrenia. N. Engl. J. Med. 354, 472-482. doi:10.1056/NEJMoa053222

Horacek, J. (2000). Novel antipsychotics and extrapyramidal side effects. Theory and reality. Pharmacopsychiatry 33, 34-42. doi:10.1055/S-2000-7660

Jerrell, J. M., and Ramirez, P. M. (2008). Changes in neuropsychological functioning following treatment with risperidone, olanzapine, and conventional antipsychotic medications. Hum. Psychopharmacol. 23, 595-604. doi:10.1002/hup.967

Kapur, S., and Seeman, P. (2001). Does fast dissociation from the dopamine D-2 receptor explain the action of atypical antipsychotics?: a new hypothesis. Am. J. Psychiatry 158, 360-369. doi:10.1176/appi.ajp.158.3.360

Keefe, R. S., Bilder, R. M., Davis, S. M., Harvey, P. D., Palmer, B. W., Gold, J. M., et al. (2007a). Neurocognitive effects of antipsychotic medications in patients with chronic schizophrenia in the CATIE trial. Arch. Gen. Psychiatry 64, 633-647. doi:10.1001/archpsyc.64.6.633 
Keefe, R. S., Sweeney, J. A., Gu, H., Hamer, R. M., Perkins, D. O., McEvoy, J. P., et al. (2007b). Effects of olanzapine, quetiapine, and risperidone on neurocognitive function in early psychosis: a randomized, double-blind 52-week comparison. Am. J. Psychiatry 164, 1061-1071. doi:10.1176/appi.ajp.164.7.1061

Krakowski, M. I., Czobor, P., and Nolan, K. A. (2008). Atypical antipsychotics, neurocognitive deficits, and aggression in schizophrenic patients. J. Clin. Psychopharmacol. 28, 485-493. doi:10.1097/JCP.0b013e3181855cd6

Lee, M. A., Jayathilake, K., and Meltzer, H. Y. (1999). A comparison of the effect of clozapine with typical neuroleptics on cognitive function in neurolepticresponsive schizophrenia. Schizophr. Res. 37, 1-11. doi:10.1016/S0920-9964(98) 00145-5

Lee, S. M., Chou, Y. H., Li, M. H., Wan, F. J., and Yen, M. H. (2007). Effects of antipsychotics on cognitive performance in drug-naive schizophrenic patients. Prog. Neuropsychopharmacol. Biol. Psychiatry 31, 1101-1107. doi:10.1016/j. pnpbp.2007.03.016

Leucht, S., Cipriani, A., Spineli, L., Mavridis, D., Orey, D., Richter, F., et al. (2013). Comparative efficacy and tolerability of 15 antipsychotic drugs in schizophrenia: a multiple-treatments meta-analysis. Lancet 382, 951-962. doi:10.1016/S01406736(13)60733-3

Leucht, S., Samara, M., Heres, S., Patel, M. X., Furukawa, T., Cipriani, A., et al. (2015). Dose equivalents for second-generation antipsychotic drugs: the classical mean dose method. Schizophr. Bull. pii, sbv037. doi:10.1093/schbul/sbv037

Leucht, S., Samara, M., Heres, S., Patel, M. X., Woods, S. W., and Davis, J. M. (2014). Dose equivalents for second-generation antipsychotics: the minimum effective dose method. Schizophr. Bull. 40, 314-326. doi:10.1093/schbul/sbu001

Lindenmayer, J. P., Khan, A., Iskander, A., Abad, M. T., and Parker, B. (2007). A randomized controlled trial of olanzapine versus haloperidol in the treatment of primary negative symptoms and neurocognitive deficits in schizophrenia. $J$. Clin. Psychiatry 68, 368-379. doi:10.4088/JCP.v68n0303

Ljubin, T., Zakic Milas, D., Mimica, N., Folnegovic-Smalc, V., and Makaric, G. (2000). A preliminary study of the comparative effects of olanzapine and fluphenazine on cognition in schizophrenic patients. Hum. Psychopharmacol. 15, 513-519. doi:10.1002/1099-1077(200010)15:7<513::AID-HUP213>3.0. $\mathrm{CO} ; 2-\mathrm{Y}$

McGurk, S. R., Carter, C., Goldman, R., Green, M. F., Marder, S. R., Xie, H., et al. (2005). The effects of clozapine and risperidone on spatial working memory in schizophrenia. Am. J. Psychiatry 162, 1013-1016. doi:10.1176/appi.ajp.162.5. 1013

Mehta, S. H., Morgan, J. C., and Sethi, K. D. (2015). Drug-induced movement disorders. Neurol. Clin. 33, 153. doi:10.1016/j.ncl.2014.09.011

Meltzer, H. Y., Bobo, W. V., Roy, A., Jayathilake, K., Chen, Y., Ertugrul, A., et al. (2008). A randomized, double-blind comparison of clozapine and high-dose olanzapine in treatment-resistant patients with schizophrenia. J. Clin. Psychiatry 69, 274-285. doi:10.4088/JCP.v69n0214

Mori, K., Nagao, M., Yamashita, H., Morinobu, S., and Yamawaki, S. (2004). Effect of switching to atypical antipsychotics on memory in patients with chronic schizophrenia. Prog. Neuropsychopharmacol. Biol. Psychiatry 28, 659-665. doi: 10.1016/j.pnpbp.2004.01.019

Mortimer, A. M., Joyce, E., Balasubramaniam, K., Choudhary, P. C., and Saleem, P. T. (2007). Treatment with amisulpride and olanzapine improve neuropsychological function in schizophrenia. Hum. Psychopharmacol. 22, 445-454. doi:10. 1002/hup.865

Muscatello, M. R., Bruno, A., Pandolfo, G., Mico, U., Scimeca, G., Di Nardo, F., et al. (2011). Effect of aripiprazole augmentation of clozapine in schizophrenia: a double-blind, placebo-controlled study. Schizophr. Res. 127, 93-99. doi:10.1016/ j.schres.2010.12.011

Nielsen, R. E., Levander, S., Kjaersdam Telleus, G., Jensen, S. O., Ostergaard Christensen, T., and Leucht, S. (2015). Second-generation antipsychotic effect on cognition in patients with schizophrenia - a meta-analysis of randomized clinical trials. Acta Psychiatr. Scand. 131, 185-196. doi:10.1111/acps.12374

Pantelis, C., Stuart, G. W., Nelson, H. E., Robbins, T. W., and Barnes, T. R. (2001). Spatial working memory deficits in schizophrenia: relationship with tardive dyskinesia and negative symptoms. Am. J. Psychiatry 158, 1276-1285. doi:10. 1176/appi.ajp.158.8.1276
Patel, M. X., Arista, I. A., Taylor, M., and Barnes, T. R. E. (2013). How to compare doses of different antipsychotics: a systematic review of methods. Schizophr. Res. 149, 141-148. doi:10.1016/j.schres.2013.06.030

Potvin, S., Aubin, G., and Stip, E. (2015). Antipsychotic-induced parkinsonism is associated with working memory deficits in schizophrenia-spectrum disorders. Eur. Arch. Psychiatry Clin. Neurosci. 265, 147-154. doi:10.1007/s00406-0140511-y

Purdon, S. E., Jones, B. D., Stip, E., Labelle, A., Addington, D., David, S. R., et al. (2000). Neuropsychological change in early phase schizophrenia during 12 months of treatment with olanzapine, risperidone, or haloperidol. The Canadian collaborative group for research in schizophrenia. Arch. Gen. Psychiatry 57, 249-258. doi:10.1001/archpsyc.57.3.249

Purdon, S. E., Malla, A., Labelle, A., and Lit, W. (2001). Neuropsychological change in patients with schizophrenia after treatment with quetiapine or haloperidol. $J$. Psychiatry Neurosci. 26, 137-149.

Riedel, M., Muller, N., Spellmann, I., Engel, R. R., Musil, R., Valdevit, R., et al. (2007a). Efficacy of olanzapine versus quetiapine on cognitive dysfunctions in patients with an acute episode of schizophrenia. Eur. Arch. Psychiatry Clin. Neurosci. 257, 402-412. doi:10.1007/s00406-007-0748-9

Riedel, M., Spellmann, I., Strassnig, M., Douhet, A., Dehning, S., Opgen-Rhein, M., et al. (2007b). Effects of risperidone and quetiapine on cognition in patients with schizophrenia and predominantly negative symptoms. Eur. Arch. Psychiatry Clin. Neurosci. 257, 360-370. doi:10.1007/s00406-007-0739-x

Salem, A., and Moustafa, A. A. (2015). A commentary on "antipsychotic-induced parkinsonism is associated with working memory deficits in schizophreniaspectrum disorders". Front. Behav. Neurosci. 9:131. doi:10.3389/fnbeh.2015. 00131

Sergi, M. J., Green, M. F., Widmark, C., Reist, C., Erhart, S., Braff, D. L., et al. (2007). Social cognition [corrected] and neurocognition: effects of risperidone, olanzapine, and haloperidol. Am. J. Psychiatry 164, 1585-1592. doi:10.1176/ appi.ajp.2007.06091515

Smith, R. C., Infante, M., Singh, A., and Khandat, A. (2001). The effects of olanzapine on neurocognitive functioning in medication-refractory schizophrenia. Int. J. Neuropsychopharmacol. 4, 239-250. doi:10.1017/S146114570100253X

Sweileh, W. M., Odeh, J. B., Shraim, N. Y., Zyoud, S. H., Sawalha, A. F., and Al-Jabi, S. W. (2014). Evaluation of defined daily dose, percentage of British national formulary maximum and chlorpromazine equivalents in antipsychotic drug utilization. Saudi Pharm. J. 22, 127-132. doi:10.1016/j.jsps.2013.03.003

van Veelen, N. M., Grootens, K. P., Peuskens, J., Sabbe, B. G., Salden, M. E., Verkes, R. J., et al. (2010). Short term neurocognitive effects of treatment with ziprasidone and olanzapine in recent onset schizophrenia. Schizophr. Res. 120, 191-198. doi:10.1016/j.schres.2010.04.011

Velligan, D. I., Newcomer, J., Pultz, J., Csernansky, J., Hoff, A. L., Mahurin, R., et al. (2002). Does cognitive function improve with quetiapine in comparison to haloperidol? Schizophr. Res. 53, 239-248. doi:10.1016/S0920-9964(01)00268-7

Wagner, M., Quednow, B. B., Westheide, J., Schlaepfer, T. E., Maier, W., and Kuhn, K. U. (2005). Cognitive improvement in schizophrenic patients does not require a serotonergic mechanism: randomized controlled trial of olanzapine vs amisulpride. Neuropsychopharmacology 30, 381-390. doi:10.1038/sj.npp.1300626

Wu, J. Q., Chen, D. C., Xiu, M. H., Tan, Y. L., Yang, F. D., Kosten, T. R., et al. (2013). Tardive dyskinesia is associated with greater cognitive impairment in schizophrenia. Prog. Neuropsychopharmacol. Biol. Psychiatry 46, 71-77. doi:10. 1016/j.pnpbp.2013.06.013

Conflict of Interest Statement: The authors declare that the research was conducted in the absence of any commercial or financial relationships that could be construed as a potential conflict of interest.

Copyright (c) 2015 Potvin and Tikàsz. This is an open-access article distributed under the terms of the Creative Commons Attribution License (CC BY). The use, distribution or reproduction in other forums is permitted, provided the original author(s) or licensor are credited and that the original publication in this journal is cited, in accordance with accepted academic practice. No use, distribution or reproduction is permitted which does not comply with these terms. 